\title{
Correction to: Gun Violence and Barriers to Reparation in the United States: Scars of Survival
}

\author{
Sanhita Ambast, Anne FitzGerald, and Malavika Vartak
}

\section{Correction to:}

Chapter 21 in: M. Crandall et al. (eds.), Why We Are Losing the War on Gun Violence in the United States, https://doi.org/10.1007/978-3-030-55513-9_21

The authorship list on this chapter is incorrect. The correct authorship is: Sanhita Ambast (corresponding author), Anne FitzGerald and Malavika Vartak.

The new authorship list also corrects the spelling of the name of Anne FitzGerald.

The affiliation of the authors also is incorrect. The correct affiliation is: Amnesty International, International Secretariat, London, UK.

In addition, the report from which this chapter is taken is by Amnesty International, International Secretariat, not Amnesty International as stated. 